\title{
IRREVOCABLE POWERS: COGNOVIT NOTES
}

\author{
MeRTON L. Ferson*
}

\section{INTRODUCTION} NE FORM OF promissory notes used in some states contains a
provision that reads substantially as follows:

The undersigned hereby authorizes any attorney-at-law . . . , after the above obligation becomes due ... to waive the issuing and service of process and confess a judgment against the undersigned in favor of any holder of this note. ${ }^{1}$.

Notes containing such a provision, called cognovit notes, present many legal questions regarding the clause. Is the power to confess judgment as recited in a cognovit note valid? Can it be revoked by the maker? Does the death of the maker end the power? If the power survives can it be executed after the maker's death?

Some judges have frowned on cognovit notes.2 A few states have

* Ph.B. I900, LL.B. 1901, A.M. 1905, University of Iowa; LL.D. 1947, University of Cincinnati. Professor of Law, University of California, Hastings College of the Law; Dean Emeritus, University of Cincinnati College of Law. Author, THE Rational Basis of Contracts (1949), Principles of Agency (1954). Contributor to legal periodicals.

${ }^{\text {I It }}$ will be observed that the power to confess judgment is given to an "attorncy at law" - not to the holder of the note. This is in order to conform to early statutes. In early common law, a court would not render judgment unless both parties litigant were in court. It was not always convenient that both parties should be present, and statutes were passed whereby an attorney at law (who was an officer of the court) could stand in for an absent party. 3 BLAckstone, Commentaries 25.

2 "A warrant of attorney authorizing judgment is perhaps the most powerful and drastic document known to civil law ... . The signing of a warrant of attorncy is equivalent to a warrior of old entering a combat by discarding his shicld and breaking his sword." Justice Musmanno, in Cutler Corp. v. Latshaw, $374 \mathrm{~Pa}$. I, 4, 97 A.2d 234,236 (1953).

"Oppression and tyranny would follow the footsteps of such a diversion in the way" of security for delst." Judge Graves, in First Nat'l Bank v. White, 220 Mo. 717, 736, I 20 S.W. ${ }_{3}^{6,4} 4$ (1909).

"[I]t is against the policy of our law to permit a man, when entering into an obligation, to bargain away his right to be heard in court, should a question cver arise between him and his adversary in relation to it ..." Crim v. Crim, I 62 Mo. 544, 564,63 S.W. 489,494 (1901) (dissent). 
condemned the use of such notes by statutes that vary in terms all the way from making the cognovit clause void ${ }^{3}$ to providing that any person who shall procure and possess such a note is guilty of a misdemeanor. And a few courts have held such provisions invalid even where they were not made void by statute. ${ }^{5}$ Other courts uphold the cognovit clause, ${ }^{6}$ and judges sometimes commend it as a convenient device. ${ }^{7}$ Owing to the varied treatment the cognovit provision has received from courts and legislatures, an examination of the theoretical and practical considerations involved may be worthwhile. Let us first sketch the law and theory with regard to irrevocable powers in general, and then consider cognovit notes in particular.

The grantor of a power can generally revoke it at will. But in exceptional cases, powers are irrevocable. Why in these exceptional cases are the powers irrevocable?

\section{I}

\section{The Agent's Powers: His Contract Rights}

Let us start from scratch. (a) An agent has power to bind his principal according to the terms of his authorization. For example, the authorization may empower an agent to sell and thus to pass the ownership of property from his principal to another. (b) The same agent may also have rights against his principal according to a contract between them. For example, the agent may be given a contract right that the principal shall pay the agent for his services. Although it is not necessary that there be a contract between a principal and his agent,

${ }^{3}$ E.g., KY. Rev. Stat. $\$ 381$ (1955).

'E.g., Ind. ANn. Stat. $\$$ 2-2906 (1933); N.M. Stat. ANN. \$ 21-9-18 (1953.). See also Ariz. Rev. Stat. ANn. § 6-629 (1956); LA. Const. art. 7, § 44.; Tex. REv. Civ. STAT. art. 2224 (1950). A cognovit clause contained in a note does not void the entire instrument, but only the cognovit provisions. Ritchey v. Gerard, 48 N.M. 452, 152 P.2d 394 (1944). For comments on the Indiana statute, see Ogden, Negotiability of Judgment Notes, 3 IND. L. J. 695 (1928); Gavit, Indiana Cognovit Note Statute, 5 IND. L. J. 208 (1929); Farabaugh \& Arnold, The Cognovit Note Act, 5 IND. L. J. 93 (1929).

${ }^{5}$ E.g., A. B. Farquhar Co. v. DeHaven, 70 W. Va. 738,75 S.E. 65 (19i2). Such provisions, even when upheld, are.strictly canstrued. Spence v. Emerine, 46 Ohio St. 433, 2 I N.E. 866 (1889); First Nat'l Bank v. White, 220 Mo. 717, I 20 S.W. $3^{6}$ (1909).

E.g., Van Norman v. Gordon, 172 Mass. 576, 53 N.E. 267 (1899).

7 "The judgment note is now in wide use, and is recognized as a very, converient and valuable security in the business world." Pirie v. Conrad, 97 Wis. 150, 153, 72 N.W. 370,37 I (1897). 
it is consistent and common for the parties to create both an agency and a contract between themselves.

It makes for clear thinking to keep in mind-and separately-an agent's powers and his rights. A power may be the subject matter of a right. One who confers a power can contract that he will not revoke the power. When such a contract has been made, it is like other contracts, in that it can be broken. The principal can revoke the power, but in doing so, he violates his duty under his contract.

When a principal breaks a contract he has made not to revoke his agent's power, the breach, like any breach of contract, raises the question: What can the victim (the agent in this case) do about it? What legal remedy or remedies are available to him?

\section{II}

\section{Remedies: Damages and Specific Performance}

There were for centuries, in most jurisdictions, two sets of courtslaw and equity. In some jurisdictions the double system still exists. But in a majority of jurisdictions the two systems of courts have been merged. When the law and equity courts were separate, they both dealt on occasion with broken contracts. But the remedies available, and the conditions on which they would be granted, differed in the law and equity courts. Those differences have carried over and exist in the courts that came about from the merger. Let us notice briefly and broadly those differences.

Suppose the victim of a broken contract brought his suit in a law court. The law court virtually would say to the plaintiff: "We cannot get for you the actual performance to which your contract entitles you. We can, however, give you a judgment for damages to compensate you for your loss. That is the remedy we grant. It will have to do as a substitute for the performance you should have." And, says Professor Walsh,. "As a remedy it has all the defects of a substitute for the real thing." "

Next, suppose that the victim of the breach had brought his suit in the equity court. That court would have said to the plaintiff "If we entertain your case at all and find the defendant in default, we shall require him actually to perform according to his obligation. But, note this! We will not give you any relief if damages (obtainable in a law

\footnotetext{
${ }^{8}$ WAISH, EQUITY 300 (1930).
} 
court) is a fairly adequate substitute for performance. Such is our remedy and the condition on which we grant it."

The action for and recovery of damages continues to be the most common remedy for breach of contract. But there has been a steady gain in the allowance of specific performance as a remedy in contract cases, especially in jurisdictions where the law and equity courts have been merged. ${ }^{9}$

\section{III}

\section{Specific Performance of Contracts Not to Revoke}

The term "irrevocable power" may seem to indicate that there is something peculiar about the power. But the irrevocability is not due to a feature of the power itself. It is due to an ancillary contract whereby the principal has undertaken that he will not revoke the power. In many situations, the breach by a principal of his contract not to revoke his agent's power cannot be atoned for by a judgment for money damages. It may, for example, be impossible to calculate the damages in such a case and, therefore, specific performance is a superior remedy. ${ }^{10}$

In some cases where contracts are broken there is a solid objection to the granting of specific performance as a remedy, because it is difficult and even impossible to supervise and compel the performance. ${ }^{11}$ For instance, a contract to render service consisting of an affirmative act or series of acts is difficult to enforce. The specific enforcement of such a contract also interferes with personal liberty.

No such objection exists with regard to a principal's contract that he will not revoke his agent's power. No supervision is required. The principal's contract calls for an omission to act. Specific performance is attained simply by holding that the power is irrevocable. ${ }^{12}$

This simple form of specific performance is illustrated in early cases that led up to the assignability of claims. Before the fifteenth century, claims were not assignable. ${ }^{13}$ It was possible, however, for the owner

\footnotetext{
II.

${ }^{10}$ Eastern Rolling Mill Co. v. Michlovitz, $x_{57}$ Md. 5x, 445 Atl. 378-(x929); Pittenger Equipment Co. v. Timber Structures, Inc., 189 Ore. 1, 217 P.2d 770 (1950); National Surety Corp. v. Titan Const. Corp., 26 N.Y.S.2d 227 (Sup. Ct. 1940); Armstrong v. Stifler, 189 Md. 630, 56 A.2d 808 (1948); CoRBIN ON Contracts $\$$ I $_{42}$ (1951); Williston on Contracts $\$ 14 \times 8$ (rev, ed.) (1936); REstatement, CoNTRACTs $\$ 358$ et seq. ( 9932 ).

${ }^{11}$ WALSH, op. cit. supra note 8 , at 335 .

${ }^{22}$ LattX, INTRoduction to Business Associations 470 et seq. (195I).

${ }^{10}$ M.P. v. J.R., 37 Hen. VI, $\mathrm{f}_{13}, \mathrm{pl}_{3}$ (1458).
} 
of a claim to appoint an attorney to collect the claim and to agree that such attorney might keep the proceeds. ${ }^{14}$ This appointment and agreement accomplished about the same thing as an assignment of the claim would have accomplished. . But the position of the attorney was not secure so long as the owner might revoke the agent's power, or the bankruptcy of the owner might take away the claim. ${ }^{15}$ This agency arrangement came to be called an assignment. Courts of equity were first.to hold that the power and right of the agent were not defeated by the bankruptcy or death of the owner-principal. ${ }^{16}$ Law courts soon took the same view. Said Ashurst, J., in a court of law: "Of late years, it has been found productive of great expense to send the parties to the other side of the Hall."1t In an opinion by Judge Story, the Supreme Court of the United States held that an assignor (principal) could not dismiss an action brought for the use of the assignee. ${ }^{18}$ It thus appears that the firm position of the assignee was established by the specific performance-without bills in equity-of the assignor's contracts not to revoke the assignee's powers.

Says Professor Williston: ${ }^{19}$

The assignment for value of an intangible contract right may be most accurately looked upon as creating an irrevocable legal power of attorney to enforce the assignor's right with authority to keep the proceeds when reduced to possession, coupled with an equitable ownership of the right prior to its collection.

\section{IV}

Power Coupled With An Interest

One situation where a power is deemed irrevocable is this: $P$, the owner of a thing sells a part ownership of the thing to $A$ and gives $A$ power to sell $P$ 's remaining interest. There is thus created a divided ownership of the thing, and an express or implied contract that $P$ will not revoke $A$ 's power. The power is not irrevocable by reason of any quality inherent in the power. It is irrevocable because the principal has expressly or impliedly contracted not to revoke it, ${ }^{20}$ and money damages

"LiLly's Practical Register 48 (17xo).

${ }^{15}$ Blackwell v. Litcott, 2 Keb. 33 I, 84 Eng. Rep. 206 (K.B. 1669).

${ }^{16}$ Crouch v. Martin \& Harris, 2 Vern. 595, 23 Eng. Rep. 987 (Ch. 1707); Row v. Dawson, $x$ Ves. Sen. 331, 27 Eng. Rep. 1064 (Ch. 1749).

${ }^{27}$ Winch v. Keley, x T. R. 619,99 Eng. Rep. $\times 284$ (K.B. 1787 ).

${ }^{18}$ Welch v. Manderville, 14 U.S. (I Wheat.) 233 (1816).

${ }^{20}$ Williston, op. cit. supra note 10, § 404 .

${ }^{20}$ Sinart v. Sandars, 5 C.B. 895, 136 Eng. Rep. 1132 (1848); Smith v. Brasseale, 213 Ala. 387 , 105 So. 199 (1925); 'Raleigh v. Atkinson, 6 M. \& W. 670, $15 \times$ Eng. 
is not an adequate remedy for a breach of that contract. There are many variations of this general type. The agent's interest may be legal or equitable. It exists, for example, in cases of pledges, sellers' liens, mortgages, conditional sales, and cases where a seller-shipper takes a bill of lading that makes the goods deliverable to his own order or to the order of a bank. In such cases, the creditor has an irrevocable power to sell the debtor's interest if the debtor defaults.

The phrase "power coupled with an interest," in its technical.sense, means that the agent has an interest in the subject matter of the powernot merely an interest in having a transaction made. An agent's interest, for example, in closing a deal and thus earning a commission is not a power coupled with an interest that would make his power irrevocable. ${ }^{21}$ And a contract that an agent shall have an interest in the proceeds of a sale does not give the agent an interest in the subject of the sale. It does not make his power irrevocable. ${ }^{22}$

An impression sometimes exists that "power coupled with an interest" and "irrevocable power" are synonymous phrases. But a power may be irrevocable for other reasons. When, for example, a principal gives a power together with a contract not to revoke it and does so by

Rep. 581 (Exch. I840). "A Court will not decree the specific performance of a contract unless there is a valid contract to be enforced." CoRBIN, op. cit. supra note ro, $\$$ I 140 . "The requisites of a contract are the same in equity as at law." WILLISTON, op. cit. supra note 1o, $\$$ I4I8.

A power is itself an "interest" as that term is defined in the Restatement, PropERTY $\& 5$ (1936). But a power does not lift itself by its bootstraps and become irrevocable because it is itself an interest. A broad view of the cases seems to indicate that in order for a power to be a "power coupled with an interest," it must be coupled with a right, privilege, or immunity pertaining to the subject of the power. And even then, the irrevocability derives not from the coupling alone, but from a contract of the principal not to revoke. If the agent's power and his interest come to him from different parties, so that there are no facts from which to infer a contract not to revoke, the power is revocable. Smith v. Brasseale, 2I3 Ala. 387, I05 So. I99 (1925); Black v. Harsha, 7 Kan. App. 794, 54 Pac. 2 I (1898). See also Ferson, Principles of Agency $\S 206$ (1954).

${ }^{22}$ Hunt v. Eunis, 12 Fed. Cas. 9I3 (No. 6889) (C.C.R.I. I82I). Hunt v. Rousmanier's Adm'rs, 2 I U.S. (8 Wheat.) I 74 ( $182_{3}$ ) ; Farmers L. \& T. Co. v. Wilson, I39 N.Y. 284, 34 N.E. 784 (1893); Frink v. Roe, 70 Cal. 296, I I Pac. 820 (1886); Cox v. Freeman, 204 Okla. I38, 227 P.2d 67o (x95 I); O'Connell v. Superior Court, 2 Cal.2d 4I8, 4 I P.2d 334 (I935); McKellop v. Dewitz, 42 Okla. 220, I40 Pac. 1161 ( $\left.19 \mathrm{I}_{4}\right)$.

${ }^{29}$ Schilling v. Moore, 34 Okla. 155, I25 Pac. 487 (1912); Chase v. Holmes, r9 Cal. App. 670, 127 Pac. 652 (I912); Lowell v. Hessey, 46 Colo. 517, ro5 Pac. 870 (1909); Jacksonville Terminal Co. v. Smith, 67 Fla. 1o, 64 So. 354 (r9 I $_{4}$ ); Browne v. King, rg6 S.W. 884 (Tex. Civ. App. 1917), aff'd, I I I Tex. 330, 235 S.W. 522 (x92I); Todd v. Superior Court, I8I Cal. 406, I84 Pac. 684 (Igrg). 
way of securing the agent that some other obligation will be performed, the power is irrevocable. ${ }^{23}$ This amounts to specific performance of the principal's contract. It is in accord with cases where specific performance is sought by bill in equity on contracts made as security. ${ }^{24}$

In some instances, a power that was irrevocable for another reason has been called a power coupled with an interest. For example, Judge Farmer of the Illinois Supreme Court says this: "We think it must . . . be held that the power to confess judgment was given as security to the creditor; that it was therefore coupled with an interest."205 The predication that a power is coupled with an interest because it is irrevocable puts the cart before the horse. When a power is coupled with an interest it is usually irrevocable. But a power may be irrevocable although it is not coupled with an interest-e.g., when it is given as security. Said Judge Sherick, in Schuck v. McDonald: "It is the reasoning or conclusion that such a power of attorney [irrevocable] is a 'power coupled with an interest' that creates the rub.",26

The Cognovit Note: Not a Power Coupled with an Interest

A cognovit clause in a note does not create a power coupled with an interest. There is no division of interest in the note; the holder owns it. He, of course, is interested in collecting it and hopes to acquire the proceeds, but he does not share the ownership of the note with any one. He does not need any power from the maker to collect or dispose of his own note.

The power to confess judgment recited in a cognovit note looks forward to a possible acquisition, by the holder of the note, of an interest in things the maker shall own when the note matures. The cognovit clause provides a quick, easy, and inexpensive way to exchange the note for judgment and thus to make collection. The maker has contracted to leave this power open. Specific performance of the maker's contract, by deeming the power irrevocable, is obviously a suitable remedy.

Does the cognovit clause, in addition to facilitating the collection of

${ }^{23}$ Restatement (SECOND), Agency § 139 (1958).

${ }^{24}$ National Surety Corp. v. Titan Const. Corp., 26 N.Y.S.2d 227 (Sup. Ct. ig40). "Where the contract of agency is specifically enforceable, e.g., where a power of sale is given as security, the attempt to revoke the agency could be frustrated in equity, and a court of law reaches the equitable result by declaring the agency irrevocable." 37 Harv. L. Rev. 253 (1923).

${ }^{25}$ Johnson v. Nat'l Bank, 320 Ill. $389,395,151$ N.E. 231, 233 (1926). (Emphasis added.) See also Carmichnel's Case, $[1896] 2 \mathrm{Ch} .643$.

${ }^{20} 5$ Ohio App. 394, 400, 16 N.E.2d 619, 622 (1938). 
the note, serve also to give the holder of the note property security that the note will be paid? It does not purport to give the holder any immediate interest in things that belong to the maker. Should it be construed to give the holder an interest in things the maker may have when the note matures? That seems doubtful. Such a construction would impress a secret lien on everything the maker had or might get by the time the note matures-a lien unlimited in extent and nondescriptive in coverage.

There is authority for the proposition that a mortgagor's present assent that the mortgage shall cover property later acquired by him will operate to vest the mortgagee with an equitable interest in such property when acquired by the mortgagor. (The two theories that are most commonly used to account for this result are these: first, the mortgagor's agreement that his future property shall be mortgaged should be specifically enforced; ${ }^{27}$ second, a presently manifested intent to transfer or create an interest in property to be acquired in the future should be operative when the property is acquired.) ${ }^{28}$ Whatever may be the theoretical basis for vesting a mortgagee with an interest in afteracquired property of the mortgagor, this qualification exists: the property must be described so as to identify it between the parties and put third parties on notice. ${ }^{29}$

These equitable mortgage cases do not support the idea that the holder of a cognovit note has an interest in all the property that the debtor may own when the note matures. In the leading equitable mortgage case, Holroyd v. Marshall, ${ }^{30}$ the machinery to be added to the mill was expressly made subject to the mortgage and became clearly identified when installed in the mill. The cognovit note cases fall short in two important particulars. First, the property that might become subject to a judgment lien is not identified. Second, it is not even agreed by the parties that a lien shall attach until the agent shall exercise his option to exchange the note for a judgment.

\section{VI}

\section{Cognovit Note: Death of Maker}

Suppose that the maker of a cognovit note dies, the power to confess judgment against the maker not having been exercised. Does the power

${ }^{97}$ Holroyd v. Marshall, ro H.L. Cas. 191, Ix Eng. Rep. 999 (1862).

${ }^{28}$ Tailby v. Official Receiver, 13 App. Cas. 523 (1888).

20 Osborn, Mortgages 92 (1951).

${ }^{30}$ xo H.L. Cas. I 9 1, ir Eng. Rep. 999 ( 1862 ). 
to confess judgment held by "any attorney at law" for the benefit of the holder make him a secured creditor? The question is important in cases where the estate is insolvent. If the note has been secured by an interest in property of the debtor, such as a mortgage, pledge, or seller's lien, the death of the maker would not snuff out such interest. And the power supported by such an interest would still be available. "The general rule of law is that where the authority of the agent is so coupled with an interest in the subject matter of the agency it is not terminated by the death of the principal, and a subsequent execution of it by the agent will be good." ${ }^{31}$ In that situation, the mortgagee or other interest holder is virtually a trustee who holds a specific res, the beneficial ownership of which is vested partly in him and partly in the debtor. The important fact is that the agent's interest is vested before the principal dies.

The problem is different when the agent has only a naked power to confess judgment. In that case, the purpose of confessing judgment is to get an interest-a lien-that the creditor does not have in things that were owned by the debtor, now deceased. The difference in the situation of a power-holder who has an interest in specific property of his debtor and a power-holder who does not have such an interest is stated by Judge Wiest in Chrysler Corp. v. Blozic as follows: ${ }^{32}$

"A 'power is coupled with an interest' when the writing conveys, or vests in the agent, an interest or estate in the thing or property which is the subject of the agency, as distinguished from the proceeds or result of the exercise of the agency, Filtsch v. Bishop, I I 8 Okl. 272, 247 P. I I ro (Syllabus). - In Chase Nat'l Bank of New York v. Sayles (C.C.A.) Ir F.(2d) 948, 957, it was said: "We hold it to be clear that the interest which can protect a power, after the death of a person who creates it, must be an interest in the thing itself; in other words, the power must be ingrafted on an estate in the thing...."

A power to create and then to have an interest in the thing created, if not consummated, does not survive the death of the grantor of the power.

The power to confess judgment given by the maker of a cognovit note and his contract that the power will not be revoked are inserted to facilitate collection of the note. And let us assume that it was intended also to secure that the note would be paid. The contract obligation of the maker not to revoke, like his other contract obligations, falls on his

\footnotetext{
${ }^{31}$ Mechem, Agency $\$ 655$ (2d ed. 1914).

${ }^{33} 267$ Mich. 479, 481, 255 N.W. 399, 400 (1934).
} 
estate. And the reasons for deeming the power irrevocable are as cogent now as they were while the maker lived. That does not mean that the holder of the note has an interest in the things that belonged to the maker when he died. An agent's interest in the subject matter makes his power irrevocable, but cause and effect do not operate in reverse. The fact that an agent's power is irrevocable does not give him an interest in the property involved.

The holder of a cognovit note has, at best, only a power to exchange his note for a judgment. ${ }^{33}$ He cannot get a judgment against the deceased maker, for a court will not render a judgment against a dead man. ${ }^{34}$ The judgment, therefore, could only be against the executor or administrator in his representative capacity. That brings us to the question of how the erstwhile holder of a cognovit note, presently a judgment creditor of the maker's insolvent estate, shall fare in competition with other creditors as they all compete for the assets in the estate. Priorities, if any, among creditors of the estate are determined on facts existing at the time of the debtor's death. ${ }^{35}$ Said Judge Ladd in Blackman v. Baxter Reed E' Co.: "There can be no race between creditors for the assets of a dead man. After his demise neither the recording of an incumbrance nor the taking of possession can confer a preference.

${ }^{s s}$ Let us notice an analogous situation. One who has an option to buy land has no interest in the land. Pending the exercise of his option there is no equitable conversion. Says Professor Walsh: "Where an option to purchase is exercised after the death of the vendor, his heirs or devisees are entitled to the purchase money, as the property passed to them as realty on the vendor's death, because an option is not a contract to sell which may be specifically enforced, and therefore the vendor-purchaser relation does not arise until the exercise of the option after the vendor's death." Assuming the validity of a cognovit clause, the holder of a cognovit note has what is virtually an option to turn in the note and take summary judgment. But until he exercises that option, he has no interest in the maker's property. WALSH, op. cit. supra note 8, at 417. See also Pound, Progress of the Lazw, 33 HARv. L. Rev. 8 I $_{3}$ (1920).

34 Schuck v. McDonald, 58 Ohio App. 394, 16 N.E.2d 619 (1938); Irose v. Balla, 18 I Ind. 491, I04 N.E. 85 I (1914); Maddock v. Stevens, 3 N.Y. Supp. 528 (Snp. Ct. I 888); Lanning v. Pawson, $38 \mathrm{~Pa} .480$ (186I) ; Stucker v. Shumaker, 290 Pa. 348, 139 Atl. 114 (I927); Johnson v. Nat'l Bank of Mattoon, 320 Ill. 389 , I 5 I N.E. 23 I (1926) (dictum); Black, JuDGMENTS $§$ I99 (2d ed. I 902); Kager v. Vickery, 6I Kan. 342, 59 Pac. 628 (1900). Although the death of one who has issued a cognovit note will render the power to confess judgment ineffectual, supervening insanity of the maker does not have that effect. A court is still able to enter judgment against a living person. Swisher v. Orrison Cigar Co., Ohio St. I95, I7 N.E. 92 (1930); Johnson v. Nat'l Bank of Mattoon, supra.

${ }^{35}$ Farmville Oil \& Fertilizer Co. v. Bourne, 205 N.C. 337, I7 I S.E. 368 (i933). See also Anonymous, 2 N.C. 295 (1796); 24 C.J. Executors and Administrators $\$ 1156$ n. 18. 
All rights are of necessity to be adjudicated as of the date of decedent's death."${ }^{336}$ The net result is that the holder of a cognovit note has no security when the maker dies insolvent. The holder of such a note gets only his percentage along with the other general creditors. ${ }^{37}$

\section{VII}

\section{Hunt v. Rousmanier}

The monumental case of Hunt $v$. Rousmanier ${ }^{38}$ presented one phase of the problem that arises on the death of one who has made a cognovit note. In that case, a creditor tried to cut himself in as a secured creditor on the strength of an irrevocable power to sell property of the deceased debtor. He was not allowed to do so.

The facts in that case were these: Rousmanier, a borrower who owned certain vessels, gave Hunt, the lender, power of attorney to sell the vessels, if Rousmanier should default in paying the notes held by Hunt. The powers were given "with the full belief that they would, and with the intention that they should, give the plaintiff as full and perfect security as would be given by a deed of mortgage."30 Rousmanier died insolvent, the notes remaining unpaid. Hunt took possession of the vessels and brought a bill in equity wherein he prayed that the administrators be decreed to join in a sale of the vessels and "pay out of the proceeds the debt due to the plaintiff. ${ }^{340}$ Since Rousmanier died insolvent, there must have been other creditors. The plaintiff was, therefore, asking to be treated as a secured creditor-i.e., secured by a lien on the vessels. Justice Marshall took the view that the power, having been given as security, was irrevocable by Rousmanier during his life but was terminated by his death. ${ }^{41}$

${ }^{36}{ }_{125}$ Iowa 118, roo N.W. 75 (1904). See also Raybourn v. Creger, 204 Iowa 961, 216 N.W. 272 (1927); American Notes in 2 ENG. RUL. CAS. 206 (1902); In re Elam's Estate, 104 Colo. 126, 89 P.2d 243 (1939); O'Hara v. Manley, 140 Pa. Super. 39, 12 A.2d 820 (1940); In re Luce's Estate, 137 Neb. 846, 291 N.W. 562 (1940).

${ }^{37}$ Some states give a preference to creditors who procured judgments before the debtor died. But a creditor who procures his judgment after the death of his debtor takes only a pro rata share with other creditors. McConnell v. Barnes, 142 S.C. 112 , 140 S.E. 310 (1927).

${ }^{38} 21$ U.S. (8 Wheat.) $174(1823)$. ${ }^{30} I d$. at 176.

$\therefore$ Ibid.

41 The wisdom of the decision is suggested by Dean Latty in the following passage: "Even accepting the Restatement view" (death of the creator of the power does not terminate the power) 'does it follow that today in an identical situation the 'agent' in Hunt's position could take possession of the ships, sell them, apply the proceeds to his claim, leaving other creditors of the insolvent debtor that much worse off? If the 
Marshall notes that a creditor, in attempting to execute the power would have to do so in the name of the debtor. That is not a convincing reason for the decision. But a more basic reason is given for the decision: $:^{2}$

This general rule, that a power ceases with the life of the person giving it, admits of one exception. If a power be coupled with an "interest," it survives the person giving it and may be executed after his death ... [W] [Wat is meant by the expression, "a power coupled with an interest?" . . We hold it to be clear, that the interest which can protect a power, after the death of a person who creates it, must be an interest in the thing itself. In other words, the power must be engrafted on an estate in the thing.

And so, according to Hunt v. Rousmanier, a power coupled with an interest and a power given to secure the agent are alike irrevocable by the principal. But if the principal dies, the effect on the power holder differs in the two cases. If the agent has an interest, he can keep it and cash in on it. But if the agent has not an interest, it is too late for him to act in behalf of his erstwhile principal and get an interest. ${ }^{43}$ Hunt's unexecuted power to sell the vessels and take the proceeds to the extent of his claim fell short of giving him an interest in the vessls. Hunt had no property security when Rousmanier died. The doctrine of the case is supported by other decisions. ${ }^{44}$

Marshall says that Hunt's power became "extinct" when Rousmanier died. On the other hand, the Restatement of Agency says that a power given as security is not terminated by the death of the creator of the power. ${ }^{45}$ Does this verbal contradiction mean that the result would have been altogether different if the Restatement had been in existence and

existence of that power of attorney was unknown to the creditors (particularly creditors who extended credit after the creation of this power), might it not in effect be the equivalent of a secret lien on those ships, in violation of the policy of the law (manifested by many specific rules) against secret liens?" LATTY, op. cit. supra note 12, at 479. While Dean Latty sees wisdom in the actual decision in Hunt $v$. Rousmanier, he is critical of Chief Justice Marshall's rationale and of his concept of "agency coupled with an interest."

${ }^{12}$ Hunt v. Rousmanier's Adm'rs, 2 I U.S. (8 Wheat.) I74, 203-04 (1823).

43 "There can be no agent where there is no principal." Weber v. Bridgman, $1_{3}$ N.Y. 600, 605, 2 I N.E. 985,987 (I889).

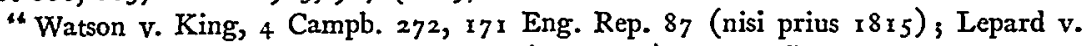
Vernon, 2 Ves. \& B. 5x, 35 Eng. Rep. 237 (Ch. 18I3); McGriff v. Porter, 5 Fla. 373 (1853); Re Tabbagh's Estate, I69 Misc. 463, 3 N.Y.S.2d 542 (1938); Schuck v. McDonald, 58 Ohio App. 394, 16 N.E.2d 6 I9 (1938). Contra, Lightner's Appeal; 82 Pa. $301(1876)$.

${ }^{20}$ Restatement (Second), Agency $\$$ I39 (x933). 
had been applied to the facts of the case? Would Hunt, in that event have been allowed to sell the vessels and take the proceeds to the exclusion of Rousmanier's other creditors?

It must be remembered that Hunt had no interest in the ships. While an agent's interest in the subject matter of his power makes his power irrevocable (if there is an express or implied contract by the principal not to revoke it), an irrevocable power does not per se give the agent an interest in the subject matter. Hunt's claim was based on (a) his irrevocable power to sell the vessels-i.e., put across their titles, and (b) the agreement that he might keep the proceeds. The contest among the creditors was with regard to the proceeds of the sale. There is a factual difference between a thing and its "proceeds." The courts definitely recognize that difference. ${ }^{46}$

Marshall's statement that Hunt's power of attorney was "extinct" when Rousmanier died is in verbal disagreement with the Restatement, but his hunch that all of Rousmanier's creditors should share equally the assets of his insolvent estate seems sensible and in accord with probate law.

Let us turn from the theoretical to the practical. Should a creditor who holds an irrevocable power be able to grab the subject of his power to the exclusion of other creditors?

In Hunt v. Rousmanier, for instance, if Hunt's power could be exercised and he were allowed to keep the proceeds, it would seem that a like power and privilege could have been given by Rousmanier with regard to everything he had or might get. The supposition can be pressed further. What would there be to prevent Rousmanier from giving to others the same power and privilege, and with regard to the same vessels, that he had given Hunt? If such secret and unrecorded arrangements were upheld, the administrator of Rousmanier's estate might have the assets of the estate sold from under him and the proceeds already allocated to secret creditors. It should be remembered that it is not merely a question of the agent's power. The crux of the question is: Who gets the proceeds? It is basic in the administration of estates that the law sticks a peg at the moment a person dies. $\mathrm{He}$

${ }^{4}$ Bonney v. Smith, 17 Ill. 53 I (1856); Green v. Cole, 103 Mo. 70, 15 S.W. 317 (1890); Coburn v. Davis, 20x Iowa 1253, 207 N.W. 586 (x926); Chambers v. Seay, 73 Ala. 372 ( 1882 ) ; McGriff v. Porter, 5 Fla. 373 (1853); Onyx Refining Co. v. Evans Production Corp., 182 F. Supp. 253 (N.D. Tex. 1959); Huffcut, AGENcx $\S 72$ (2d ed. 1901); TIFFANY, AGENCY $\$ 88$ (2d ed. 1924). 
gives up at that point, and the administrator begins. It would seem that when things belonging to the estate are sold, the proceeds should accrue to the administrator for the benefit of all creditors of the deceased.

\section{Summary}

A principal sometimes contracts that he will not revoke the power he gives. In such a case, the agent's power and his contract right are separate things. The contract, like most contracts, can be broken; and in case of a breach, the remedy most commonly allowed to the victim is a judgment for damages. In exceptional cases, a judgment for money damages is not an adequate remedy for the breach and a court will grant a simplified form of specific performance. That consists of holding that the power is irrevocable. When an agent's power is coupled with an interest in the subject matter of the power it is irrevocable; and so it is if the power is given as security. There are still other grounds for holding a power irrevocable.

A cognovit clause in a promissory note is deemed in some jurisdictions to be valid. In other jurisdictions, it is banned by statute or judicial fiat. Such a clause does not interfere with the negotiability of the note. ${ }^{47}$ The charge that the cognovit clause is harsh is open to question. Its operation, when deemed valid, tends to reduce the bother and expense of collecting the note, without extending the liability of the maker. It cuts off no defense that would not be cut off by negotiation of the note.

The holder of a cognovit note should not fancy, however, that the cognovit clause gives him any property security before the power is exercised. If the maker of such a note dies before the power has been exercised, the holder has, according to the Restatement of Agency, just what he had before the maker died-i.e., a power to exchange his note for a judgment. But, since a court will not render a judgment against a dead man, the judgment could be rendered only against the maker's estate. Such a judgment would be no better than any other judgment procured after the maker died.

${ }^{\text {"N.I.L. }}$ § j. 